\title{
Recent developments in South African
}

\section{Jesus research: From Willem Vorster}

\section{to Andries van Aarde}

\author{
A G van Aarde
}

University van Pretoria

\begin{abstract}
In the previous article (see HTS 49/3) the work of Andrie du Toit and Willem Vorster on historical Jesus research were discussed. In this article Andries van Aarde's work is discussed under the following topics: Jesus as a social outcast, Herodian Palestine in macrosociological perspective, the historical Jesus and engaged hermeneutics, and the 'fatherless' Jesus. In conclusion, the kind of influence that South African Jesus research is subjected to or stimulated by is shown.
\end{abstract}

\section{INTRODUCTION}

In the previous article the work of Andrie du Toit and Willem Vorster on historical Jesus research were discussed. In my own approach to historical Jesus research, as in the case of Du Toit and Vorster, issues regarding the philosophy of science are taken as point of departure. In several articles (which do not focus on the quest for the historical Jesus as such) my position in this regard has been spelled out and it is still in the process of being shaped. To me, biblical scholarship today, like any other postmodern scientific reflection, is featured among other things by its multi- and

\footnotetext{
- An expanded version of a paper presented at the International Meeting of the Society of Biblical Liter ature, Westfălische Wilhelms-Universität Münster, Germany, $26 \mathrm{July} 1993$. Financial assistance from the Centre for Science Development is hereby acknowledged. In the previous essay (sec Van Aarde 1993b), I focused on the work of Andrie du Toit and Willem Vorster on historical Jesus research.
} 
interdisciplinary character. The use of narratological and sociological theories and models in exegesis is a demonstration of the issues which nowadays constitute the agenda of biblical scholarship. It is within this paradigm that social-scientific criticism is worth mentioning. This approach in biblical interpretation has brought several unexploited aspects of the cultural background of the New Testament to the fore. Impasses in current research have been studied anew. Earlier debates have been re-opened, in the hope that they can solve problems in nature with regard to present-day societal issues or at least be intelligible in terms of a credibile explanation of the problems of our day.

A growing awareness of ethnocentrism is perhaps one of the many important advantages which has occurred as a result of social-scientific criticism. Ethnocentrism boils down to a realization of the cultural distance between ancient and modern societies, and among particular cultures in a given period. This awareness has significant ethical implications for Christian practice inferred from biblical scholarship. With regard to ethics, the New Testament has often been interpreted without a sensibility of the historlcal distance between the first century and the twentieth century. Economical and political forces behind modern social dichotomies are often ascribed to the conditions that were presumably present in the world of Jesus or the early church. In other words, ancient pre-industrial documents are being interpreted from the perspective of our present-day societal structures. The result is not only ethnocentrism but also reductionism.

Ethnocentrism amounts to an association of irreconcilable cultural phenomena which cannot stand the test of a responsible cross-cultural enterprise. Reductionism, on the other hand, is also a form of misplaced concreteness. It occurs, for example, when someone tries to explain a broad spectrum of intertwined socio-religious phenomena from a perspective framed by the dynamics of either one or two social institutions. Proponents of such an approach are often found among historical-nıaterialistic interpreters of the Bible. In this regard references within the (preindustrial) Bible to alienation from resources and to ostracism from societal structures are ascribed to the kind of economic and political ideologies that Karl Marx identified with regard to the modern industrial society. Social science criticism, however, makes us aware not only to cross-cultural similarities, but also to differences in cosmology, ideology and mythology. This awareness is particularly important for historical Jesus research. The overview of my own work comprises five subsections: Jesus as a social outcast, Herodian Palestine in macrosociological perspective, the historical Jesus and engaged hermeneutics and, finally, the 'fatherless' Jesus. 


\section{JESUS FROM THE SIDE}

\subsection{Jesus as a social outcast}

My first work on historical Jesus research was initiated by an attempt to challenge this hermeneutical fallacy of misplaced concreteness. It was written in 1988 under the heading 'Jesus and the social outcasts' ['Jesus en die sosiaal-veragtes']. The sociological model that served as the frame of reference within which I substantiated the hypothesis of my study was at that time largely based on the work of Bruce Malina (1986a, 1986b) and Paul Hollenbach (1987). According to this model social interactions should be understood against the background of the hierarchical structures of a 'total society'.

The thrust of my argument was that ostracism corresponds to these hierarchical structures or the institutional order found in a particular society. The expression 'institutional order' implies that a balanced society consists of particular social institutions, one of which is the overarching one, while the others are integrated with it in subordinate fashion. At least four basic social institutions or structures can be discerned within any society: economy, politics, family life and religion. In certain societies today the economy forms the basis of social relations. One may also find that politicians exercise control over economic and religious institutions. There are, however, societies in which families and the heads of families exercise the control. The Mediterranean world of the first century is an example. In such societies religion, politics and economy were embedded in an institutional order of family life which was primarily determined through birth and nationality. Applying this insight to the world of the New Testament, Malina (1989:131) convincingly demonstrated that

the Mediterranean world treats this institution [kinship] as primary and focal....In fact in the whole Mediterranean world, the centrally located institution maintaining societal existence is kinship and its sets of interlocking rules. The result is the central value of familism. The family or kinship group is central in social organization; it is the primary focus of personal loyalty and it holds supreme sway over individual life.

This is therefore tantamount to anachronism, misplaced concreteness, as well as reductionism, if the phenomenon of social injustice in the world of Jesus is to be understood only, or even primarily, in terms of modern economic and political concerns. Economic and political steps taken in the first century that led to ostracism, for example, should be interpreted in terms of the above social scientific model and perspective in the light of the primary familial structures of the period and the social, mythological and religious symbols representing these structures. 
Although my use of sociological models at that time can certainly be regarded as the work of a dilettante, several aspects of my portrayal of the historical Jesus in that particular study have become to me more and more intelligible as my application of socialscientific criticism has increased over the past five years. To name some elements: Jesus' non-apocalyptic use of the metaphor 'kingdom of God'; Jesus' experience of God's unmediated presence in the midst of and despite depressing circumstances; Jesus' concept of God in terms of a familial relationship between a father and a son; Jesus' temple critique; his death as the result of a falsely assumed political program; Jesus' a-political attitude'; Jesus himself as a social outcast (and not a kind of Robin Hood figure born within an imperial kingdom who only docetically fulfilled the role of being one of the poor in his act of being the hero of the helpless in society).

\subsection{Herodian Palestine in macrosociological perspective}

In a more recent article, entitled 'Aspects of the social stratification of the advanced agrarian society in first-century Palestine' ['Aspekte van die sosiale stratifikasie van die ontwikkelde agrariese samelewing in die eerste-eeuse Palestina'], I took one step further to explain the relationship between the historical Jesus as a social outcast himself and the other 'nobodies' in his society (cf Van Aarde 1993a). The dynamics of social interactions in his time is understood in terms of the social stratification of first-century Palestine. My study rests to a large extent on the work and insights of colleagues with whom I have been privileged to collaborate internationally within the framework of The Context Group - A project on the Bible in its cultural environment. More specifically, it was triggered by responding to the challenge that Carolyn Osiek (1992a), a New Testament scholar from Chicago, issued. In her revised and expanded second edition of What are they saying about the sociology of the New Testament?, she challenged in a particular way the social-scientific critics who saw as their task the explanation of the social context of the New Testament. She asked exegetes to take their own contexts into consideration as well (cf also Osiek 1992b).

Osiek's remark should be understood against the critique of Itumeleng Mosala, a biblical scholar from Cape Town in South Africa (1989a). Mosala criticized recent sociological studies in biblical exegesis. According to him they maintain, just as in traditional historical criticism, the social and political agenda of the current governing classes. Mosala is of the opinion that 'sociological exegesis' does not really reckon with the aspects of class, ideology and political economy of the biblical world. It also does not take into consideration the class, ideology and political eco- 
nomy of the so-called 'biblical sociologist'. Instead, it covertly protects $\mathrm{it}^{2}$. He therefore dismisses sociological studies of the Bible as 'one step forward but two steps backwards'. According to him, their point of departure is still to be found in a kind of rationality base which is ideologically biased, like First-World oriented historical criticism. Within such an ideological mentality, 'knowledge' (in this regard, social sciences) becomes a manipuiative and exploitative force for the maintenance of self-interests, like the technocracy of the Western world and its traditional religiosity.

Personally, I had considered it as important for social-scientific exegetes to gain prior clarity for themselves on the issue of the characteristics of the social stratification of the biblical world and, specifically, in my case the so-called 'advanced agrarian society' of Herodian Palestine in which the historical Jesus lived. I made specific use of the insights of the macro-sociologist, Gerhard Lenski ${ }^{3}$ and the publications of David Fiency (1991) and Dennis Duling (1991), who structured their work upon Lenski's macrosociology. The specific originality of my own contribution rests upon the assumption that the 'ideological' function of kinship as a social institution shifted in an evolutionary fashion when horticultural societies changed into simple agrarian and then into advanced agrarian societies. Initially, kinship, and especially the 'extended family' as social unit, had been the primary and focal institution in society. According to cultural anthropologists it was clearly observable at the surface level of horticultural and simple agrarian societies as well. However, the shift from a horticultural (7000 - 3000 BCE) to an agrarian society (3000 BCE - $1800 \mathrm{CE}$ ) changed this dominant role of the extended family with regard to the dynamics of social life. Instead, political economy had become at the surface of society the most dominant factor. This process reached its zenith during the so-called advanced agrarian society which commenced round about $500 \mathrm{BCE}$. The last phase shifted again during the Industrial Revolution which, during the latter part of the eighteenth century, was well under way. Political economy has since become an ideotogy in the sense of what Karl Marx referred to as 'false consciousness'.

The hypothesis of my article was that, although kinship had been put under tremendous stress during the time of the advanced agrarian society because of political and economical dichotomies so that the extended family almost ceased to be seen on the surface level of Herodian Palestine, family interests moved to the deep structure of society and developed into an ideology comparable with the notion of false consciousness. In other words, family interests in the world of the historical Jesus were as ideologically conditioned as materialism in industrial societies. Against this macrosociological background and especially in the light of the advanced agrarian society of Herodian Palestine, Jesus' critique of the patriarchal family and paradoxi- 
cally his experience of God's kingdom as a brokerless household, amidst depressing circumstances, grew more intelligible to me and became an explanatory power.

\section{The historical Jesus and engaged hermeneutics}

The above-mentioned article on aspects of the social stratification of first-century Palestine did not focus on the accusation that traditional biblical scholarship has led to ideological manipulation and exploitation. However, this very point received attention in my latest research project, undertaken during the 1992-1993 academic year at the Institute for Ecumenical and Cultural Research in Collegeville (Minnesota). The title of this project was: "The epistemic status of the New Testament and the emancipatory living of the historical Jesus in engaged hermeneutics'. In this study I responded to another challenge by Carolyn Osiek (1992a, 1992b), issued in the publications mentioned earlier. This referred to the the implications of social science criticism for liberation theology. More specifically, I paid attention to the role of historical Jesus research in what I called 'engaged hermeneutics'.

My study aimed at transcending particular shortcomings in existing contextual hermeneutical studies and to propose an alternative design for engaged hermeneutics. The intention was that this design should be adequate for all exegetes and not only for those who represent the marginalized in society. The purpose was the broadening of the point of departure and the circle of conversational partners in contextual hermeneutics in order to emancipate the 'oppressor' as well as the 'oppressed'. In radical liberation theologies we find an alternative point of departure in theological inquiry - that is, the economically poor, the politically oppressed, and the socially destitute, and not the 'givenness' of an 'infallible' Bible, an 'infallible' church or the 'inherent' rationality of the human mind as in traditional FirstWorld theologies (cf Robert McAfee Brown 1978:60-62). Hence, the conversational partner in Third-World theologies ${ }^{4}$ is the nonperson, the peripheral person, and not the 'non-believer', for whom belief has become difficult in an age of science.

In the light of our present-day postmodern global culture, First-World theologians are challenged to coalesce with Third-World theologians. The institutionalized and Westernized church and we, as First-World theologians, have to become more aware of our own 'base communities'. In a certain sense, from the perspective of contextual theology, one can argue that engagement with these communities forms the essence of Christian belief and of doing theology. Such an enterprise is conditioned by the identification of commonalities in theological inquiry in both traditional theology and contextual theology. Hermeneutics of the Bible, and especially of the New Testament, is an important common ground for 'traditional 
theology' and 'contextual theology' alike. Both theologies hold onto the importance of Scripture as the source for theology. More specifically, again in reference to a remark by Willem Vorster mentioned in the previous article, Jesus of Nazareth is seen as the 'answer' (cf Breech 1989:13; Vorster 1993:1) to our problems in the First as well as in the Third World.

I argued, however, that there is a foundational reason why the historical Jesus and not the canon should be seen as the common ground for the engagement by First as well as Third World theologians. It relates to the epistemic status of the canon in liberation theology and especially in feminist theology. Traditional hermeneutics tends to accept the authority of the canon and tradition. Its deepest wish is to allow tradition to be transmitted with its original force and it is therefore blind to the view of the canon as an ideological vehicle for domination and oppression. Therefore, in engaged hermeneutics one is challenged to reflect on the ideologically conditioned origins of the canon. I indicated that the canon originated during the time when the horticultural society shifted to an agrarian one. Cultural anthropologists demonstrate that this shift was accompanied by the emergence of world religions, the process of urbanization, the growth of conquest states, the increase of inequality in social stratification and the increase in the scarcity of resources. Simultaneously, writing and money were invented as media in the control of the scarce resources through power and the unequal distribution of authority. From the perspective of radical contextual theologians one can argue that the process of 'canonization' functioned as a medium through which illiterate masses were influenced to accept the authority of the 'conventional wisdom' of 'court prophets' and 'scribal sages'.

In South Africa, within this same vein, Itumeleng Mosala argued that the Bible should be seen as a complex text best understood as itself a signified practice.

As such, the Bible is coded differently in literary, political, cultural and ideological terms. It cannot be...seen merely as a straightforward mirror of events in Ancient Israel [or first-century Palestine - AGvA]. On the contrary it is a production, a remaking of those events and processes. More specifically, some...'layers's...of the Bible are cast in 'hegemonic codes' which represent social and historical realities...in terms of the interest of the ruling classes. Other [layers] of the Bible are encoded in 'professional codes' which have relative autonomy, but which still operate within the hegemony of the dominant code. Other [layers] of the Bible are signified through 'negotiated codes' which contain a mixture of adaptive and oppositional elements, but which still take the dominant codes as their starting point. Still other [layers] 
of the Bible represent 'oppositional codes' which are grounded in the interest and religious perspectives of the underclasses of the communities of the Bible.

(Mosala 1989b; cited by West $1991: 110$ )

Instead of a historical-critical, or even a social-historical approach to the Bible, Mosala6, following Norman Gottwald (1985), advocates a 'historical-materialist' reading as an appropriate critical tool to unmask hegemonic codes embedded in the Bible and in the dispositions of the exegete as well. Although Mosala does not demonstrate it himself, the historical Jesus tradition belongs to the so-called 'oppositional codes'.

Against this background, the Jesus of history preserves that which is 'subversive' in our memory of Jesus. The Jesus of history keeps us in touch with the radicality of his emancipatory living. It is a dimension that can easily be lost as tradition develops. The development of the traditions needs always to be measured against the historical words and deeds of Jesus (cf Tracy 1981:233-247; Thompson 1985:106107; Hill 1991:44-46). Mosala, however, showed that liberation theologians often interchange the notion 'Word of God' with either 'Moses' or 'Jesus'. Therefore, he although a historical-materialistic liberation theologian ${ }^{7}$ - is critical towards the tendency within liberation theology to rely naive-realistically on either 'Moses' or 'Jesus'. He rightly demontrated that such a norm amounts to reductionism. The Bible is 'reduced to a simple socially and ideologically unmediated' norm taken from the face value of the 'Word of God'8.

But that does not mean that I personally do not regard knowledge about the historical Jesus as essential for being a Christian in the past as well as in the present. Marcus Borg (1987:201-202 note 9), however, has an interesting more subtle view on this issue. For him, 'historical knowledge about Jesus' is not 'essential for the life of Christian discipleship' (my emphasis). According to Borg 'historical knowledge about Jesus is no more necessary for the life of discipleship than it is for Christian faith'. 'Nevertheless,' he continues, 'what Jesus was like is not irrelevant to discipleship. Indeed, we may suppose that for the earliest Christians in the first decades after Easter, the still-vivid historical memory of what he was like must have shaped their understanding of what it meant to "follow him."' Borg says: 'My claim is simply that an image of the historical Jesus illuminates the path of discipleship' (my emphasis). However, in the light of my reflection on the role of the historical Jesus in engaged hermeneutics, I disagree with Borg in spite of the many similarities between his portrait of the historical Jesus and my own historical understanding of Jesus. Holding onto the importance of the dialectic between our understanding of the historical Jesus and our reading of ancient texts as the 'classical witnesses to 
New Testament Christianity' is, to me, not only desirable but also essential for engaged hermeneutics in general and for being an engaged Christian today.

The interest of liberation theologians in the historical Jesus, however, separates them from scholars who are involved in the so-called quest for the historical Jesus. Liberation theologians are not on a quest to establish 'objective data' to recover precisely what Jesus said and did. Rather, they want to understand the relevance of the historical Jesus for their own context. In this respect, their approach to the Bible provides an example of the model of interpretation as conversation (cf Pope-Levison \& Levison 1992:31). Nevertheless, engagement with Jesus, as opposed to recovering Jesus, requires holding together in creative fusion two distinct horizons: the historical Jesus and the present-day context of contemporary society. Engelbert Mveng's (1988:19) unreflective use of the term 'historical Christ' is an example of the neglect of the importance of the historical context of Jesus and the distance between then and now. To use Willem Vorster's (1993:12) phrase again: Jesus is simply taken at face value from the New Testament. What is needed is sound methodology. To me, historical Jesus research demands a three-dimensional textual investigation in engaged hermeneutics: literary, social scientific and theological. James Breech put it this way in his earlier book, The silence of Jesus: The authentic voice of the historical man:

Since our only access to the historical Jesus is through the literature produced by those who believed in him and who propagated a religious niovement in his name, we must employ the analytical techniques used by New Testament scholars in order to discriminate between the words of Jesus and the words of his worshippers.

(Breech 1983:6)

Only when one's construct of the historical Jesus is rooted in historical research research that is built upon an epistemological reflection ${ }^{9}$ and accompanied by the use of literary techniques - can one, in the words of David Tracy (1981:233-247), 'preserve that which is "subversive" and "dangerous" in the memory of Jesus'. And this finally leads me to my research in view of the planned conference by the historical Jesus subgroup of the New Testament Society of South Africa. The title of this project is: "The "third quest" of the historical Jesus - where should it begin: with Jesus' relationship to the Baptizer, or with the nativity traditions?'

\subsection{The 'fatherless' Jesus}

As mentioned earlier, Thomas Wright rightly identifies present-day historical Jesus research as the attempt first to set the historical Jesus firmly into his Jewish context 
and, second, to offer complete historical constructs about Jesus' whole life and work. My own research in this regard comprises a construct of an ideal-type of Jesus of Nazareth. The notion and use of the 'ideal-type' are commonly associated with the name of the German sociologist, Max Weber (1949:89-112). An 'ideal-type' is not a description of reality or a hypothèsis about reality. It is a theoretical construct in which possible events are intelligibly related to constitute an internally coherent system. Such a structure is constituted, not by selecting what is common to all instances, not by taking what is common to most instances, but by concentrating on the most favorable instances, namely those offering more intelligibility and explanatory power. The advantage of such an 'ideal-type' is twofold. In so far as the historical situation satisfies the conditions of the ideal-type, the situation is illuminated. In so far as the historical situation does not satisfy the conditions of the ideal-type, it brings to light precise differences that otherwise would go unnoticed, and it sets questions that might otherwise not be asked. Therefore, its utility is both heuristic and expository - that is, it can be useful inasmuch as it suggests and helps to formulate hypotheses and, again, when a concrete situation approximates the theoretical construct, it can guide an analysis of the situation and promote a clear understanding of it (cf also Lonergan 1972:227-228).

To me, as has already been shown, the thrust of Jesus' life and work was that he trusted God as his $A b b a$, and by doing so he redefined the kingdom of God in terms of a 'brokerless' household. From the perspective of this assumption a historical construct of his 'whole life' within first-century Herodian Palestine is built, according to an imaginative sociological 'ideal-type'. This 'ideal-type' should be historically intelligible and explanatory. It should rely on contemporary canonical and non-canonical texts (including artifacts) which have to be interpreted in terms of a chronological stratification of relevant documents. It should also make sense within a social stratification of first-century Herodian Palestine.

In other words, my construct of the life of Jesus, historically seen, does not start with Jesus' relationship with John the Baptist, as usually portrayed. Historically, it begins with the traditions regarding Jesus' birth record and his relationship with his family. My understanding of the starting point of the quest for the historical Jesus should be seen against the background of John Dominic Crossan's recent book, The historical Jesus: The life of a Mediterranean Jewish peasant. As Crossan in a particular sense commences with the Pauline vision of the 'crucified Jesus' as a death through which 'sin' is buried (cf also Crossan 1993), I begin with Jesus' baptism as a 'ceremonial'/'ritual' event, through which 'sinful sickness' was addressed and healed. Crossan understands the Pauline vision as 'condensed history', a plotted event that was preceded by a sequential series of other historical events prior to the crucifixion. 
I understand Jesus' baptism likewise as 'condensed history'. Why would Jesus want to be baptized? Is it because of his 'sinful sickness'? I argue that the unfortunate relationship with his family and his critique of the patriarchal family as such provide the probable clue. Moreover, what does Jesus' birth record tell us about his relationship with his family and his townsfolk in Nazareth? What does his birth record reveal about his ministry among, especially, children and other 'nobodies' in his society (cf Van Aarde 1992)? To me, the answers to these questions rely on a construct of an 'ideal-type' regarding someone in first-century Herodian Palestine who was healed from 'sinful sickness' (for example, the stigma of being a 'fatherless son') and started a ministry of healing/forgiving 'sinners' with the help of disciples who were also called upon to act as 'healed healers'. Jesus died because of the 'subversiveness' of this 'ethos of compassion' (to use an expression from Marcus Borg's [1987:131] insights) in the Jewish society of his day. His followers were likewise threatened and some died in the same manner as their forerunner had. It is my intention to demonstrate theologically, historically and in a literary fashion, how this construct is built upon available Jesus traditions in terms of chronological as well as social stratification.

Regarding a chronological stratification, Crossan (1991:427-450a), in an appendix to his book on the historical Jesus, provides a useful and excellent '[i]nventory of the Jesus tradition by chronological stratification and independent attestation'. This stratification rests on the assumption that the Jesus tradition went through three major stages of retention and recording of 'at least the essential core of words and deeds, events and happenings; another of development, applying such data to new situations, novel problems, and unforseen circumstances; and a final one of creation, not only composing new sayings and new stories, but, above all, composing larger complexes that changed their contents by that very process' (Crossan 1991a:xxxi). However, this does not mean that the first stage represents authentic information and the others not. One, therefore, needs a sequence of strata in terms of which the available traditions are chronologically stratified. Crossan compiled such a stratification consisting of four strata. However, some of the dating of documents in Crossan's chronological stratification is highly debatable. The same can also be said about some of his arguments regarding the identification of hypothetical documents. Critical modification of certain aspects of his model is therefore necessary.

The first stratum covers the earliest Christian texts which originated in the period 30-60 CE. It contains, inter alia, four authentic letters of Paul, the first layer of the Gospel of Thomas and the Sayings Gospel $Q$ (consisting of three successive layers in its development). The second stratum originated in the period $60-80 \mathrm{CE}$, and contains eight documents among which we find the Gospel of Mark and the 
Signs Gospel/Book of Signs (a hypothetical text embedded within John's gospel [chs 2-14]). The third stratum contains nineteen documents from the period 80-120 C E. It consists of, inter alia, the Gospel of Matthew, the Gospel of Luke, the Apocalypse of John, First Letter of Clement, the Epistle of Barnabas, Didache 1:1-3a and 2:216:2, Shepherd of Hermas, the Letter of James, the Gospel of John, the seven Letters of Ignatius, the First Letter of Peter, the Letter of Polycarp to the Philippians 13-14, and the First Letter of John. The fourth stratum contains twelve documents, dated from the period 120-150 CE. It consists of, inter alia, the Apocryphon of James, the Second Letter of Peter, the rest of the Letter of Polycarp to the Philippians, the Second Letter of Clement, and finally, the Gospel of the Nazarenes.

Crossan is clear that, in terms of the sequence of strata, the first stratum contains data chronologically closest to Jesus. Literary 'units' of Jesus tradition composed within the first stratum are not necessarily historically the most accurate. Theoretically, a 'unit' from the fourth stratum can be more original than one from the first stratum. Therefore, a hierarchy of attestation of 'units' and, especially, 'complexes' of 'units' is necessary, beginning with the first stratum and working from there to the second, third, and fourth. My point of departure is Crossan's finding on the 'complex' Jesus-Kingdom of God-Children. This 'complex' comprises six 'units', namely Gospel of Thomas 22:1-2; Mark 10:13-16 = Matthew 19:13-15 = Luke 18: 15-17; Matthew 18:3; John 3:1-10. Thus, it is a 'complex' which is attested by a textual 'unit' belonging to the first stratum (Gospel of Thomas) and which is supported by multiple independent attestations of the second stratum (Gospel of Mark) and third stratum (Gospel of Matthew and Gospel of John). These multiple and independent attestations show how seriously Jesus' attitude towards children should be taken historically (cf Crossan 1991a:xxxiii-xxxiv; 1991b:1200). I argue that it is possible to consider these 'children', from a perspective of the social stratification of first-century Herodian Palestine, as part of the lowest 'class', namely the 'expendables' (cf also Van Aarde 1992). Hence, I will proceed with the 'units' regarding, first, Jesus' birth record (cf the nativity traditions in the Gospels of Matthew and Luke, but also Gospel of Thomas 105; Mark 3:6; John 1:45; 6:42; 8:41; 19:9; Acts of Pilate 2:3 - cf Schaberg 1987:145-178 [esp 157-158]; Van Tilborg 1993:3-58 [esp 1821]) and, second, Jesus' family (Gospel of Thomas 99:2; Mark 3:31-35 = Matthew 12:46-50 = Luke 8:19-21; 2 Clement 9:11; Gospel of the Ebionites 5 - cf Smith 1990; Meier 1992)). For the 'a-familial ethos' of Jesus, see also the Sayings Gospel Q 9: 59-60a; 14:26; 12:51-53; 16:13; 16:18; and 17:26-27 (cf Jacobson 1992). Subsequently, my construct of the fatherless Jesus is framed in the context of the social stratification of first-century Herodian Palestine. And, finally, the construct is explained 
theologically (or rather, christologically) as a Jesus not 'from above', not 'from below', but 'from the side' (cf Malina \& Neyrey 1988:x-xi).

'Jesus from above' describes the conciliar debates about Jesus as have descended from heaven and having been incarnated on earth; Jesus was thus confessed as 'true God' and 'true man'. 'Jesus from below' refers to modern biblical scholarship where the focus is squarely on the humanity of Jesus. And because both 'christologies' represent a dialectic of vertical classification, this perspective on the person of Jesus is chiefly, if not exclusively, concerned with symbols of power or force. 'Jesus from above' reflects Christian tradition only after the time of Constantine (cf also Song 1993:57-58), when hierarchy became the expressive social structure, with power or force the primary concern. 'Jesus from below' expresses twentieth-century concerns with the relationship between natural and supernatural and the possibility of trancendence in a secular world. Both these views would be rather anachronistic for an adequate understanding of New Testament views on Jesus. Yet, within Christian groups before Constantine ${ }^{10}$, the chief expressive social dimension for nonRoman and Roman non-elite Christians was not vertical, but horizontal - 'from the side'. In short, as Malina and Neyrey (1988:xi) demonstrated, the focus is on the social processes whereby Jesus was acclaimed or defamed by members of his society who interacted with him as an equal. The difference can be explained by emphasizing the difference in connotative meaning of the relational preposition of in the phrase 'son of God' (cf my earlier reference to Vorster 1993). In terms of ontological christology, it is a relation of identification, and Jesus' Godlike equality is inferred. In terms of functional christology, it is a relation of significance, and Jesus' obedience as a 'subordinate son' is inferred. In a 'Jesus from the side' the relation between 'son' and 'God' can have a metaphorical reference (cf also Vorster 1990b: 33-51): the abandoned fatherless child metaphorically gains a heavenly father and becomes the first of the brothers and sisters in a fictive kinship. To conclude in the words of John Macquarrie (1992:42): 'To speak of Jesus as "Son of God" is to use a metaphor'.

\section{CONCLUSION}

The shift in historical Jesus research since the eighties is also represented in the work of South African scholars. Du Toit's reflection should be understood as an appraisal of the New Quest and Vorster's reflection as an appraisal of the Third Quest (see Van Aarde 1993b). Van Aarde's construct of Jesus is an example of what is meant by the phrase 'Third Quest'. According to Du Toit (1988), Jesus is part and parcel of the 'theologies' of the New Testament and not only its presupposition. 
Therefore, the quest for the 'original' Jesus is not only desirable but also essential. The need for the quest rests upon an accountability toward intra-ecclesiastical as well as extra-ecclesiastical 'truth' claims. The relevance of this accountability relates to the rational base of the gospel within a framework of inter-religious dialogue, especially between Judaism and Christianity. In the same vein, historical Jesus research has an expository power in guiding an analysis and understanding of the various 'theological developments' within the New Testament and the early church. More specifically, the challenge Du Toit proposes to exegetes is to take also the interests of the believing community into consideration - not only those of the scholarly community. More particularly, this challenge has to do with those aspects of the Jesus tradition that do not have other analogies in the historiographical sense. However, in the light of the present-day insights from the sociology of knowledge, Du Toit, in turn, is asked to reckon with the difference in the cosmological and mythological frame of reference between New Testament Christianity and the believing community today.

In his reflection on historical Jesus research, Willem Vorster moved beyond the New Quest (see Van Aarde 1993b). However, in his work it becomes also clear that so-called 'post-critical' historical research cannot be understood without considering the assumptions of the historical-critical phase. In other words, the Third Quest for the historical Jesus represents only a selective departure of aspects of the New Quest. The dispositions of the Third Quest are dialectically dependent on those of the New Quest. The term 'paradigm shift' is therefore perhaps too premature. However that may be, certain assumptions should now be seen as really something of the past. These assumptions boil down to three issues: the exclusive reliability of the canonical tradition should be left behind and the important role of the 'intracanonical' tradition (to use a term of Dominic Crossan) should be acknowledged; Jesus as a first-century Jew from Galilee should be studied like other historical persons and should not be regarded as absolutely unique; it is impossible to reconstruct the historical Jesus, his words, deeds and context - these phenomena are constructed by scholars, using whatever material is available and by applicable methods and models.

The contribution of Vorster rests especially on the compilation of what he refers to as a 'profile of presuppositions' behind the works of Jewish scholars on the historical Jesus as well as those of non-Jewish scholars. Although he did not bring this comparison into direct relation with the inter-religious dialogue as we have already referred to it with regard to Andrie du Toit's work, with this profile Vorster inaugurated a helpful starting point. Dilemmas within the inter-religious dialogue, like the 'particularity' of Jesus the Jew can be addressed in a sensible way by taking 
into consideration the assumptions in present-day historical Jesus research regarding the 'uniqueness' / 'commonality' of the Jesus of history. Such an issue has relevance not only for the relationship between the Synagogue and the Church (cf Van Aarde 1992/1993), but also for the dialogue between Christians and members of other world religions (cf Samartha 1974; Dupuis 1991; Pope-Levison \& Levison 1992; Song 1993).

As we have seen, epistemology and social science criticism are the particular characteristics of recent South African historical Jesus research. Epistemological issues deeply concerned not only Willem Vorster and myself, but in a certain sense Andrie du Toit as well. With respect to Du Toit, the point in question pertained to the dilemma of where the burden of proof should lie in relation to the argument about authenticity or non-authenticity. Du Toit admitted his reliance in this regard on the 'hermeneutics of consent' of Peter Stuhlmacher. Among recent South African scholars, however, Du Toit does not have a serious following. To me, Du Toit's use of Ernst Käsemann's notion of intra-ecclesiastical and extra-ecclesiastical accountability implies a more important epistemological issue. Unfortunately, Du Toit has not elaborated on these matters. In this regard at least two points seem to be relevant for present-day Jesus research, especially within the South African theological framework. The one pertains to traditional confessional propositions concerning the role of the canon as the boundary for investigation and the divinization of Jesus. The other point in question relates to the inter-religious dialogue and especially the so-called particularity of Jesus the Jew. As we have seen, the presuppositions which underlie the investigation into the Jewishness of Jesus constituted the main point of epistemological reflection in the work of Willem Vorster.

My own work on the historical Jesus seems to be the first attempt by a South African scholar who has begun a social scientific construction of a 'whole' life of Jesus the Jew within the context of first-century Herodian Palestine, encompassing his life from birth to death. Proceeding from this construct, I intend to accept two theological challenges. The first has to do with conceptual developments in the New Testament itself. .These developments pertain to the following: the broadening of the temple, rooted in Jesus' temple critique; the 'sharing of Jesus' sonship' by his followers and the process of his divinization, rooted in the metaphor 'son of God'; the resurrection tradition in relation to the concept of the 'new creation', rooted in Jesus' idea of humankind be born anew. The second theological challenge boils down to the relevance of historical Jesus research for the engagement of FirstWorld theologies with Third World theologies. Vorster's emphasis on the 'function of metaphorical language about the unobservable in the teaching of Jesus' can in this regard be applied to what can be called the process of 'transymbolization'. It is 
my intention to approach this issue from a cross-cultural perspective and from an engagement of First-World with Third-World christologies. The metaphor 'son of God' can hermeneutically be applied to aspects in a Third World as well as a First World context, especially in South African society where the two worlds' have to live closely together. With regard to the first, the African concept of the so-called 'elder brother' in the light of 'ancestral kinship' (cf Pope-Levison \& Levison 1992: 102-106) can be used as a case study for such an 'engaged hermeneutics'. The concern to bridge the gap between contextual theologies and the tradition of European theological thought and scholarship would be intellectually significant at any time, but in the current situation in South Africa, and in the world at large, it is critical.

\section{ENDNOTES}

1. Borg (1987:125) put it this way: 'We are not accustomed to thinking of Jesus as a political figure. In a narrow sense, he was not. He neither held nor sought political office, was neither a military leader nor a political reformer with a detailed political-economic platform. But he was political in the more comprehensive and important sense of the word: politics as the shaping of a community living in history'.

2. See Carolyn Osiek (1992b:88-95) for a critical discussion of Mosala's critique of the so-called 'sociological' analyses of the Bible.

3. Three publications of Gerhard Lenski are relevant: Power and privilege: $A$ theory of social stratification (1966), Human societies: A macrolevel introduction to sociology (1970), and especially Human societies: An introduction to macrosociology [1970] (1991). Jean Lenski was originally co-author of Human societies, and Patrick Nolan became a co-author in the sixth edition, published in 1991.

4. In 1988, in other words before the recent changes in Eastern Europe and the former Union of Soviet Socialist Republics, Leonardo Boff (1988:3-4), in an article with the striking title, "Can any good thing come out of Nazareth?": What are Third World theologies?', explains the expression 'Third World', coined by the French sociologists in the fifties, as follows: 'It designates those countries that exist on the periphery of the industrialised capitalist world (the USA and Canada, Western Europe, Japan, Australasia, making up the "First World") and outside the orbit of the socialist countries of Eastern Europe, including the USSR, which make up the "Second World"'. According to Boff, the 
main feature of the Third World is its underdevelopment: economical and technological backwardness, widespread poverty, the existence of authoritarian political institutions, illiteracy and 'the lack of participation by the people in the processes of society', and on the religious level, 'the churches dependence on those in the centre for resources, of personnel and funds, and the proliferation of charismatic sects, in which those who feel forsaken take refuge'.

5. Mosala uses the term 'parts of the Bible', but Gerald West (1991:110) rightly replaces it with 'layers of the Bible'. This replacement, however, presupposes a reliance on insights from historical-critical exegesis.

6. Cf the following remark by Mosala (1989a:9): 'The category of struggle becomes an important hermeneutical factor not only in one's reading of his or her history and culture but also in one's understanding of the history, nature, ideology, and agenda of the biblical texts. Consequently, a biblical hermeneutics of liberation, using the same tool of struggle as was used to interrogate the reader's history, culture, and ideology, must now address the question of the material conditions that constitute the sites of the struggles that produced the biblical texts'.

7. See, however, the discussion above of my own critical stance regarding the 'reductionism' of Marxist theories.

8. Perhaps the following excerpt from the article by Engelbert Mveng (1988:25) can serve as an example of what Mosala is challenging: 'So the Bible appears as one of the basic sources of Black South African theological reasoning. It is the revealed Word of God: it tells us who is man and who is God. In the Bible man is created in God's image: black, white, yellow, red, all are free and equal, in the image of God... The God of the Bible, of Exodus, the books of history, the prophets, the psalms, the books of wisdom and the gospels, is a liberating God and saviour, who protects the poor, the weak and the oppressed against the oppressor, the rich and the powerful. In South Africa the God of the Bible can only be on the side of the oppressed, namely the Blacks'.

9. The epistemological reflection on 'critical realism' as opposed to 'naïve realism' by Thomas Wright (1992a:32-44; 1992b:79) concurs with my own epistemological thinking. Wright's use of the notion 'critical realism' shows similarities with that of Ben F Meyer $(1979,1991)$. My own use of 'critical realism' was stimula- 
ted by Wentzel van Huyssteen $(1987,1989)$. He introduced me to this concept and I am still heavily dependent on his work.

10. Choan-Seng Song (1993:57-58) put it as follows: 'It began when Constantine the Great issued the Edict of Milan in 313 C.E. and made Christianity a legal religion of the Roman empire. From a historical perspective the development was so astonishing that it invited a comment such as follows:

One of the most amazing and significant facts of history is that within five centuries of its birth Christianity won the professed allegiance of the overwhelming majority of the population of the Roman Empire and even the support of the Roman state. Beginning as a seemingly obscure sect of Judaism, one of scores, even hundreds of religions and religious groups which were competing within that realm, revering as its central figure one who had been put to death by the machinery of Rome, and in spite of having been long proscribed by that government and eventually having the full weight of the state thrown against it, Christianity proved so far the victor that the Empire sought alliance with it and to be a Roman citizen became almost identical with being a Christian.

(Latourette 1953:65)

This was a truly astonishing development. But it also proved to be a fatal development. With it began the history of the Christian church in alliance with the powers that be.'

Works consulted

Boff, L 1988. 'Can any good thing come out of Nazareth?': What are Third World theologies?, in Boff \& Elizondo 1988:3-14.

Boff, L \& Elizondo, V (eds) 1988. Theologies of the Third World: Convengences and differences. Edinburgh: T \& T Clark. (Concilium: Religion in the Eighties.)

Borg, M 1987. Jesus: A new vision - Spirit, culture, and the life of discipleship. San Francisco: Harper.

Breech, J 1983. The silence of Jesus: The authentic voice of the historical man. Philadelphia: Fortress.

-- 1989. Jesus and postmodemism. Minneapolis: Fortress.

Crossan, J D 1991a. The historical Jesus: The life of a Mediterranean Jewish peasant. San Francisco: Harper. 
--- 1991b. The life of a Mediterranean Jewish peasant. The Christian Century December 18-25, 1991, 1194-1204.

--. 1993. The historical Jesus in earliest Christianity. Unpublished paper presented at the Conference, Jesus and Faith: Theologians in conversation with the work of John Dominic Crossan, DePaul University (Chicago), 4-5 February 1993.

Duling, D C 1991. Matthew's infancy in social scientific perspective: Conflict and legitimation. Unplubished paper presented at The Context Group Meeting, Portland (OR), March 1991.

Dupuis, J 1991. Jesus Christ at the encounter of world religions, transl by R R Barr. New York: Orbis Books. (Faith meets faith series.)

Fiensy, D 1991. The social history of Palestine in the Herodian period: The land is mine. Lewiston: Edwin Mellen Press. (Studies in the Bible and Early Christianity 8.)

Gottwald, N K 1985. Social matrix and canonical shape. Theology Today 42, 307 321.

Hill, B 1991. Jesus the Christ: Contemporary perspectives. Connecticut: TwentyThird Publications.

Hollenbach, P 1987. Defining rich and poor: Using social sciences, in Richard, K H (ed), SBL Seminar Papers, 50-63. Atlanta: Scholars Press.

Jacobson, A 1992. Divided families and Christian origins. Unpublished paper, Charis Ecumenical Center, Concordia College, Moorhead (Minnesota).

Latourette, K S 1953. A history of Christianity, volume 1: Beginning to 1500. New York: Harper \& Row.

Lenski, G E 1966. Power and privilege: A theory of social stratification. New York: McGraw-Hill.

--- 1970. Human societies: A macrolevel introduction to sociology. New York: McGraw-Hill.

Lenski, G, Lenski, J \& Nolan P [1970] 1991. Human societies: An introduction to macrosociology. Sixth Edition. New York: McGraw-Hill.

Lonergan, B J 1972. Method in theology. New York: Herder \& Herder.

Macquarrie, J [1991] 1992. Jesus Christ in modern thought. Second printing. London: SCM.

Malina, B J 1986a. Christian origins and cultural anthropology: Practical models for Biblical interpretation. Atlanta: John Knox.

--- 1986b. Interpreting the Bible with anthropology: The case of the poor and the rich. Listening 21, 148-159.

--- 1989. Dealing with Biblical (Mediterranean) characters: A guide for US consumers. Biblical Theology Bulletin 19/4, 127-141. 
Malina, B J \& Neyrey, J H 1988. Calling Jesus names: The social value of labels in Matthew. Sonoma: Polebridge.

McAfee Brown, $R$ 1978. Theology in a new key: Responding to liberation themes. Philadelphia: Westminister.

Meier, J P 1992. The brothers and sisters of Jesus in ecumenical perspective. Catholic Biblical Quarterty 54, 1-28.

Meyer, B 1979. The aims of Jesus. London: SCM.

-.- 1991. The challenges of text and reader to the historical-critical method, in Beuken, W, Freyne, S \& Weiler, A (eds), The Bible and its readers, 3-12. London: SCM. (Concilium.)

Mosala, I 1989a. Bilical hermeneutics and black theology in South Africa. Grand Rapids: Eerdmans.

-.- 1989b. Christianity and socialism: Approaching Moses and Jesus for national liberation in Azania. Unplubished paper, Pietermaritzburg, cited by West 1991: 10.

Mveng, E 1988. African liberation theology, in Boff \& Elizondo 1988:17-34.

Osiek, C 1992a. What are they saying about the social setting of the New Testament? Newly expanded and fully revised. New York: Paulist Press.

-.- 1992b. The social sciences and the Second Testament: Problems and challenges. Biblical Theology Bulletin 22, 88-95.

Pope-Levison, P \& Levison, J R 1992. Jesus in global contexts. Louisville: Westminister.

Samartha, S J 1974. The Hundu response to the unbound Christ. Madras: Christian Literature Society.

Schaberg, J 1987. The illegitimacy of Jesus: A feminist theological interpretation of the infancy narratives. San Francisco: Harper \& Row.

Smith, M H 1990. Kinship is relative: Mark 3:31-35 and parallels. Fonum: Foundations \& Facets 6/1, 80-94.

Song, C S 1993. Jesus and the reign of God. Minneapolis: Fortress.

Thompson, W M 1985. The Jesus debate: A survey and synthesis. New York: Paulist Press.

Tracy, D 1981. The analogical imagination: Christian theology and the culture of pluralism. New York: Crossroad.

Ukpong, J 1988. Theological literature from Africa, in Boff \& Elizondo 1988:67-75.

Van Aarde, A G 1988. Jesus en die sosiaal-veragtes. HTS 44, 829-846.

--- 1992. The Evangelium Infantium, the abandonment of children, and the infancy narrative in Matthew 1 and 2 from a social scientific perspective, in Lovering, $E$ H (ed), SBL Seminar Papers, 435-453. Atlanta: Scholars Press. 
Van Aarde, A G 1992/1993. Die breuk tussen die Sinagoge en die Kerk, en die 'uniekheid' van die vroegste Christendom. Ongepubliseerde navorsingsverslae na aanleiding van Ad hoc-navorsingstoekennings in onderskeidelik 1990 en 1991 deur die Sentrum vir Navorsingsontwikkeling van die Raad vir Geesteswetenskaplike Navorsing.

-- 1993a. Aspekte van die sosiale stratifikasie van die ontwikkelde agrariese samelewing in die eerste-eeuse Palestina. HTS 49/3, 515-545.

--- 1993b. Recent depelopments in South African Jesus research: From Andrie du Toit to Willem Vorster. HTS 49/3, 397-423.

Van der Linde, I 1990. Charismatiese moralis, revolusionêre soldaat of apokaliptiese profeet? Vrye Weekblad August 31, 1990, pp 13-14.

Van Huyssteen, J W 1987. The realism of the text. Pretoria: UNISA Publishers.

--- 1989. Theology and the justification of faith: The construction of theories in systematic theology. Grand Rapids: Eerdmans.

Van Tilborg, S 1993. Imaginative love in John. Leiden: Brill. (Biblical Interpretation Series 2.)

Vorster, W S 1990a. On presuppositions and the historical study of the Jewishness of Jesus, in Mouton, J \& Joubert, D (eds), Knowledge and method in the human sciences, 195-211. Pretoria: Human Sciences Research Council.

-- 1990b. The function of metaphorical and apocalyptic language about the unobservable in the teaching of Jesus, in Jennings, T W (ed), Text and logos: The humanistic interpretation of the New Testament, 35-54. Atlanta: Scholars Press.

--- 1993. The relevance of Jesus research for the 'new' South Africa, in Mouton, J (ed), Theology in the 1990's. Pretoria: Human Science Research Council. (Forthcoming.)

Weber, M 1949. Max Weber on the methodology of the social sciences, transl and edited by E A Shils \& H A Finch. Glencoe: Free Press.

West, G O 1991. Biblical hermeneutics of liberation: Modes of reading the Bible in the South African context. Pietermaritzburg: Cluster Publications. (Monograph Series Number 1.)

Wright, N T 1992a. The New Testament and the people of God, volume one: Christian origins and the question of God. Minneapolis: Fortress.

--- 1992b. Who was Jesus? Grand Rapids: Eerdmans. 